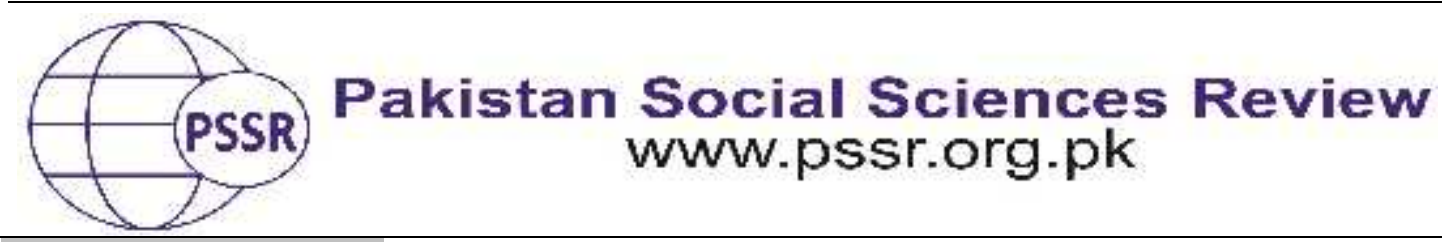

RESEARCH PAPER

\title{
The Role of Envy and Psychological Capital on Performance in Banking Industry of Pakistan
}

\section{Rehan Ahmad ${ }^{1}$ Dr Mumtaz Muhammad Khan ${ }^{2}$ Dr Muhammad Ishtiaq Ishaq ${ }^{3}$}

1. PhD Scholar, Imperial College of Business Studies, Lahore, Punjab, Pakistan

2. Associate Professor, Department of Management Sciences, Imperial College of Business Studies, Lahore, Punjab, Pakistan

3. Assistant Professor, Quaid-i-Azam School of Management Sciences, Quaid-i-Azam University, Islamabad, Pakistan

\begin{tabular}{|c|c|}
\hline PAPER INFO & ABST \\
\hline $\begin{array}{l}\text { ved: } \\
13,2020 \\
\text { ted: } \\
\text { eer } 05,2020 \\
\text { e: } \\
\text { per } 31,2020\end{array}$ & $\begin{array}{l}\text { The objective of this study is to provide a criterion for businesses } \\
\text { in making the right decisions about a conventionally negative } \\
\text { emotion such as workplace envy. This study contributes to the } \\
\text { literature by exploring the positive side of envy and by } \\
\text { comparing it with the traditional antecedent of individual and }\end{array}$ \\
\hline $\begin{array}{l}\text { Keywords: } \\
\text { OCBI, } \\
\text { OCBO, } \\
\text { Organizational } \\
\text { Performance, } \\
\text { Workplace Envy }\end{array}$ & $\begin{array}{l}\text { Such comparison can help organizations to decide if they should } \\
\text { continue their current efforts to build PsyCap or shift their focus } \\
\text { towards regulating envy. Data were collected in two waves from } \\
\text { branch managers and operations managers of } 360 \text { bank branches } \\
\text { across Punjab province in Pakistan. Combined positive effects of }\end{array}$ \\
\hline Correspondin & \\
\hline $\mathbf{A u}$ & $\begin{array}{l}\text { It is found that envy work as a stronger motivational force } \\
\text { towards favorable outcomes. Hence, it is recommended that } \\
\text { organizations should steer their efforts and resources towards } \\
\text { regulating envy. }\end{array}$ \\
\hline
\end{tabular}

\section{Introduction}

Modern organizations are the epicenter of complex emotions and relationships (Chernyak-Hai \& Rabenu, 2018). One prominent example of such complex emotions is workplace envy (Erdil \& Muceldili, 2014). There are two types of envy; malicious (negative) and benign (positive) (Lange \& Crusius, 2015; van de Ven et al., 2016). There exists a rich literature on the dark side of envy (Kim \&Glomb, 2014;Eissa\&Wyland, 2016). Nevertheless, there is a limited inquiry on the positive dimension of envy (Lee \& Duffy, 2019; Lange and Crusius, 2015; Dineen et al., 2017). While malicious envy is a cause of non-display of voluntary work behaviour such as Organizational Citizenship Behavior (Shu \& Lazatkhan, 2017; Karatepeet al., 2015), 
positive envy work as a positive motivational force for an individual to fight back and close the gap caused by upward comparison (Lee \& Duffy, 2019). As traditional positive antecedents like psychological capital (PsyCap) are generally regarded as reason for positive individual and organizational outcomes, the purpose of this study is to investigate if positive envy works as a stronger motivational force towards favorable outcomes than PsyCap.

The importance of this study can be understood from the fact that envy is an inescapable emotion which is present at all levels in almost all the organizations (Menon and Thompson, 2010). Hence, if such a widely prevailing emotion goes unattended, it can impact the organizations in all the negative ways. There is a very little difference between positive (benign) and negative (malicious) side of envy. On the one hand, benign envy is triggered if an employee perceives the advantage of the envied on merit and perceives the situation as under control(van de Ven et al., 2012). On the other hand, malicious envy is elicited if the envious thinks otherwise (van de Ven et al., 2012). Hence it is the job of the organizations to make the employee perceives that envy is in his favor in order to trigger positive dimension of envy.

It is pertinent to note that organizations spend lot of resources including, money, time, and energy to control the job stressors. Workplace envy is the most serious job stressor because it is hidden as people obscure envy due to its social undesirable nature (Vince, 2001). This can be understood from the fact that between the year 2015 and 2016, whopping 70.65 billion dollars were spent on employee training by fortune 500 companies (Statista, 2017). That is the exhaustion of economic resources alone. From the perspective of social exchange theory, resources help individuals in recognition of their social context (Fischer \&Kleef, 2010). These resources consist of hope, optimism, self-efficacy and resilience and are termed as Psychological Capital (PsyCap) (Luthans, Avolio et al., 2007). Individuals use these personal resources to view the situation as a positive stimulus which is responsible for positive behavioural outcomes such as Organizational Citizenship Behavior (OCB) and Organizational Performance (OP).

Impacts of envy on individual and organizational outcomes are present in the literature (Ghadi, 2018; Thompson et al., 2015) on both negative (Kim and Glomb, 2014, Eissa\&Wyland, 2016) and positive dimensions (Lee \& Duffy, 2019; Dineen et al., 2017). There lies research gap in the literature if organization should motivate envy or curb it. This study contributes to the literature by providing a comparative justification for the managers and consultants to make critical decision that where they should deploy their limited resources i.e., envy or PsyCap.

\section{Literature Review}

\section{A Social Exchange Model of Envy at Work}

Social Exchage Theory (SET) holds the position of gold standard in social sciences for understanding workplace behavior (Cropanzano\& Mitchel, 2005). 
Rooted back to 1920s (Malinowski, 1922), this theory has implications across various field of social sciences like social psychology (Gouldner, 1960), sociology (Blau, 1964) and anthropology (Sahlins, 1972). SET is defined as an initiating action by one party, attitudinal response from another party (reciprocity) and resulting relationship (Cropanzanoet al., 2015). SET shadows many areas such as commitment (Bishop et al., 2000), organizational citizenship behavior (Organ, 1990), organizational justice (Tepper \& Taylor, 2003) and organizational support (Ladd \& Henry, 2000).

Survival of individuals become obsolete in the absence of social relationships and emotions (Fischer \&Kleef, 2010). Not only this, maintaining relationship became increasingly challenging (Keltner \& Haidt, 1999; Fischer \&Kleef, 2010). One example of such emotions is WPE. People hide envy due to its socially undesirable nature (Vince, 2001). Eventually, envy is responsible for complex organizational relationships (Menon \& Thompson, 2010). Envy, by definition, is a pain caused by upward social comparison Tai et al. (2012). In the social exchange process, individuals feel the need to plug the gap of upward social comparison. Moreover, there are two ways through which this gap can be plugged. One is by social undermining in which the ability of the target to maintain a social relationship is impaired (Duffy, Gansteret al., 2002). Second is through the personal drive of selfimprovement in the envious (Lee \& Duffy, 2019).

Such charged envy helps an individual towards positive outcomes such as $\mathrm{OCB}$ and OP. While Organizational Performance (OP) is termed as the difference between planned and actual outcomes (Tomal and Jones, 2015), it also involves the capacity of a business to apply strategies and achieve organizational goals (Cho \& Dansereau, 2010).Organizational citizenship behavior is a non-voluntary behaviour that exceeds formal organizational duties (Zeinabadi and Salehi, 2011). We have taken OCB as an outcome to check the positive impact of Workplace Envy (WPE) and PsyCap because OCB trespasses the formal duties of an employee in an organization (Zeinabadi \& Salehi, 2011). Hence, if an employee is committed towards informal duties, it will represent genuine pledge and satisfaction of that employee towards job and organization (Organ, 1988). Similarly, such behaviours are also responsible for affirmative organizational performance. OCB is comprised of five dimensions such as conscientiousness, altruism, courtesy, sportsmanship and civic virtue. As already mentioned about the clubbed OCB classifications such as OCBI and OCBO (Lee \& Allen, 2002, Williams \& Anderson, 1991), OCB is reported as an outcome of envy in the literature (Shu \& Lazatkhan, 2017; Thompson et al., 2015). Taken together, it is theorized that workplace envy (WPE) can positively impact on individual and organizational outcomes.

$\mathrm{H}_{1}$ : There is a direct positive association between workplace envy and OCBI.

$\mathrm{H}_{2}$ : There is a direct positive association between workplace envy and OCBO.

$\mathrm{H}_{3}$ : There is a direct positive association between workplace envy and OP. 


\section{PsyCap with Positive Work Outcomes}

Psychological capital is defined as the positive psychological state of an individual which helps him in the development and has four dimensions such as hope, optimism, self-efficacy and

Ample literature is available related to PsyCap and positive individual outcomes (OCBI) as well as organizational outcomes such as OCBO and OP(Luthans, Norman et al., 2008; Luthans, Avolio et al., 2007).Concerning the first hypothesis of the study $\mathrm{H} 1$, to bridge the gap related to the object of possession, envious may use personal resources. Such personal resources work as a complementary force to enhance individual and organizational outcomes. More specifically, OCB and PsyCap are closely related, and OCB is confirmatory to organizational effectiveness (Kasa \& Hassan, 2015; Kang et al., 2019). Work of Blau (1964) provided solid grounds for Social Exchange Theory (SET) to understand OCB. Referring to SET, reciprocity in the exchange process also enables the exchange of emotions (Gouldner, 1960). Classification of OCB is common in the literature as OCBI and OCBO (Williams \& Anderson, 1991; Lee \& Allen, 2002). On the one hand, OCBI deals with behaviours of an employee towards other organizational members and while on the other hand, OCBO refers to exchanges between organizations and its employees. Both types of OCB share a common ground of being helping behaviours steered at organizations and its members. Consistency in such voluntary behaviours is also responsible for organizational effectiveness (Katariaet al., 2012; Bogler \& Somech, 2005; DiPaola \& Hoy, 2005).

$\mathrm{H}_{4}$ : There is a direct positive association between PsyCap and OCBI.

$\mathrm{H}_{5}$ : There is a direct positive association between PsyCap and OCBO.

$\mathrm{H}_{6}$ : There is a direct positive association between PsyCap and OP.

The literature on the positive spectrums of envy (Lee \& Duffy, 2019; Lange and Crusius, 2015; Dineen et al., 2017) and PsyCap (Copper-Thomas \&Morrison, 2019; Hodges, 2010; Hobfoll, 1989, 2002)is available. However, which of the two generate better work and organizational outcomes remains an unexplored area. We hypothesize that the positive impact of envy on non-voluntary behaviours and organizational performance (OP) is stronger than the impact of personal resources such as Psychological Capital (PsyCap) on Organizational citizenship behaviour $(\mathrm{OCB})$ and organizational performance (OP). OCB is clubbed in literature as OCBIndividual and OCB-organizational (Lee \& Allen, 2002; Williams \& Anderson, 1991). OCBO is organizational outcome while OCBI is an individual outcome. 
Hence, we theorize that the impact of envy is more substantial on positive work outcomes than the impact of PsyCap on similar outcomes. Specific hypotheses are stated below.

$\mathrm{H}_{7}$ : The impact of envy is more substantial on OCBI than the impact of PsyCap on OCBI such that envy generated more OCBI than PsyCap.

$\mathrm{H}_{8}$ : The impact of envy is more substantial on OCBO than the impact of PsyCap on OCBO such that envy generated more OCBO than PsyCap.

$\mathrm{H}_{9}$ : The impact of envy is more substantial on OP than the impact of PsyCap on OP such that envy generated better OP than PsyCap.

\section{Conceptual Model of the Study}

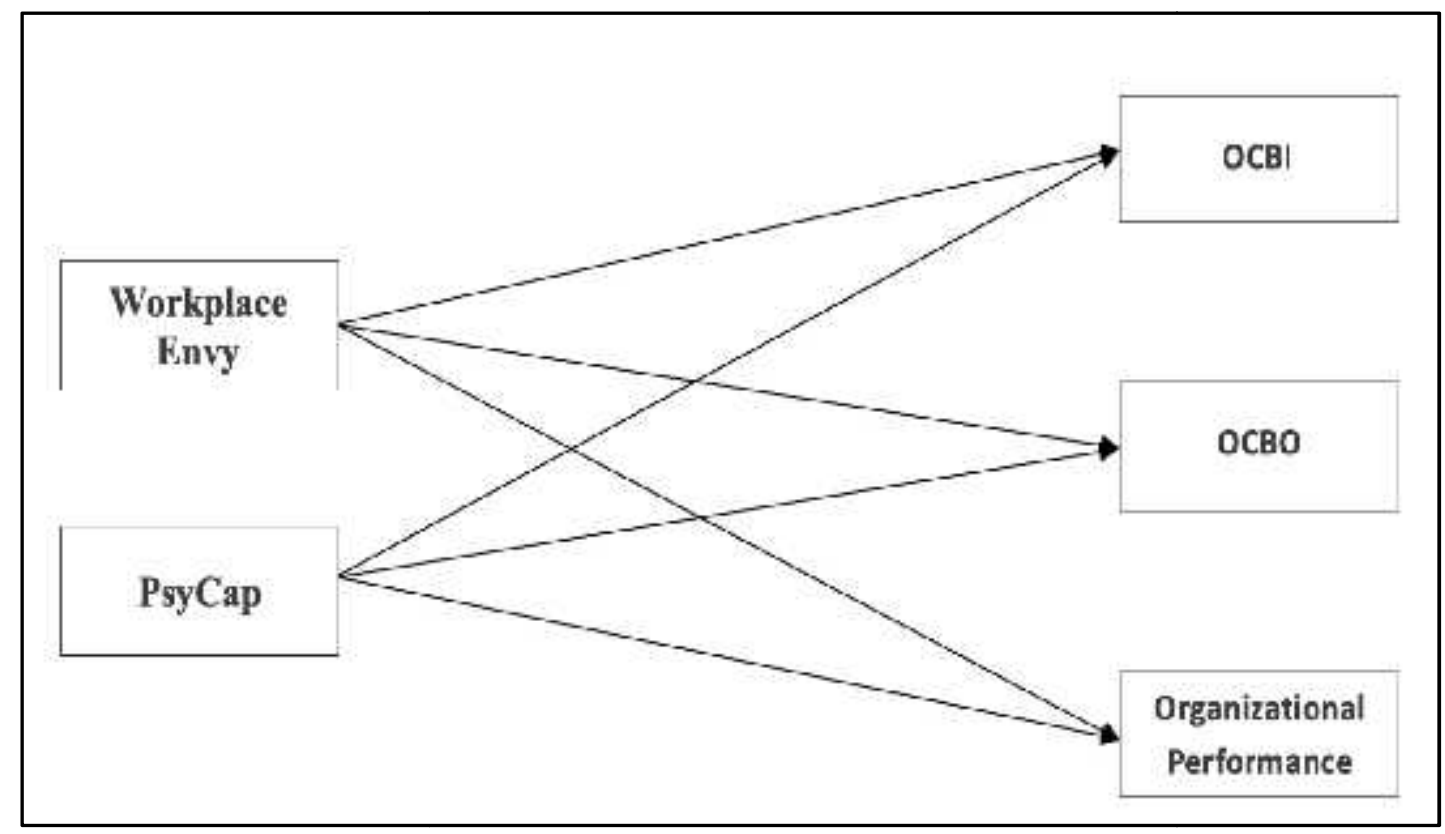

\section{Material and Methods}

Following the research onion approach proposed by Saunders et al. (2016), this study said to fall in the positivism approach due to its causal nature. We tested our hypothesized model in the banking sector in Pakistan through a two-wave study. The banking sector was selected due to its highest GDP contribution of $10.8 \%$ (Pakistan \& Gulf Economist, 2017). Out of financial (55) and non-financial (42) banking companies, we have selected financial banking companies as they perform overlapping operations of non-financial banking companies as well. Division of financial banking companies is given in Table-1.

\section{Table-1: Categorization of Financial Banking Companies}


05

Conventional

30
10

Banks

$$
\text { Microfinance }
$$

Development

Finance Institutions
10

\section{Source: State Bank of Pakistan 2018}

Conventional banks are further divided as hybrid (operating Islamic and conventional banking operations simultaneously=23) and rest are conventional banks (07). There is a total of 15,464 branches of financial banking companies in Pakistan with 2,741 branches falling in Islamic category and 12,723 branches falling in conventional banking category (State Bank of Pakistan, 2018). Among a total of five provinces in the country, 37.2\% of branches are located in Punjab province alone. Hence, the province of Punjab is selected for data collection in this study. Clusters of conventional and Islamic banks were drawn using cluster sampling based on their proportions, i.e., 5:1(298 conventional branches and 62 Islamic branches).

Data using the questionnaires via mail was collected from the operations managers in the first wave. After four weeks, in the second wave, data was collected from the branch managers. Contact details of all branches were obtained from their websites. Then a request email, containing the information of the study was sent to all the branches. A consent form was included in the email. After receiving the consent, sealed questionnaires including cover letters and return envelopes were sent to the branches by Pakistan postal service. Soft follow up calls were made on the branch numbers to guide the respondents in case of any queries.

\section{Measuring Instruments}

\section{Workplace Envy}

The scale developed by Vecchio (2005) was used to measure envy. Responses were recorded on a seven-point scale. Good reliability of this scale was recorded $(\alpha=$ $0.70)$. Many researchers recognized the psychometric properties of this scale (Thompson et al., 2015).

\section{Psychological Capital}

A short form of PCQ questionnaire developed by Luthans, Youssef et al. (2007) was adopted to measure PsyCap. This questionnaire is highly acknowledged with recognized dimensions of PsyCap such as hope (Snyder et al., 1996), selfefficacy (Parker, 1998), resilience (Wagnild, 2009) and optimism (Scheier\& Carver, 1985). This scale also showed good psychometric properties. 


\section{Organizational Citizenship Behaviour}

OCBI is estimated using seven items, and OCBO is measured through six items scale developed by Williams and Anderson (1991). This was measured using a seven-point Likert scale. Five dimensions developed by Organ (1988) which include civic virtue, conscientiousness, sportsmanship and altruism were used in the above scales.

\section{Organizational Performance}

A subjective measure of organizational performance developed by Peng et al. (2007) is used to measure organizational performance. A ten-item, seven-point Likert scale is used where 1 represented far below the competitors and 7 represented far above the competitors.

\section{Results and Discussion}

Missing values and outliers are treated using Crooks D and Mahalanobis test. Skewness and kurtosis and n-probability block were used to test data normality. Confirmatory factor analysis (CFA) and path analysis was carried out using Structural Equation Modelling (SEM). Correlation and regression tests were carried out in AMOS 18.

\section{Descriptive}

Descriptive are provided in the table- 2 about gender, marital status, age, qualification, experience and bank type. Mean, standard deviation and correlations are given in the table-3, presenting values not exceeding 0.5. Other than OCBO, all other variables found to be correlated between the acceptable range of 0.01 and 0.05 level.

\begin{tabular}{|c|c|c|c|c|}
\hline \multicolumn{5}{|c|}{ Table 2: Demographic Profile of the Respondents } \\
\hline \multirow{2}{*}{$\begin{array}{l}\text { Variable } \\
\text { Gender }\end{array}$} & \multicolumn{2}{|c|}{ Branch Manager } & \multicolumn{2}{|c|}{$\begin{array}{c}\text { Operations } \\
\text { Manager }\end{array}$} \\
\hline & $\mathbf{N}$ & Percent (\%) & $\mathbf{N}$ & Percent (\%) \\
\hline Male & 272 & 92.1 & 254 & 87.2 \\
\hline Female & 23 & 7.9 & 41 & 12.8 \\
\hline \multicolumn{5}{|l|}{ Age } \\
\hline Less than 25 years & 1 & 0.4 & 3 & 0.9 \\
\hline $26-35$ years & 120 & 40.8 & 190 & 64.5 \\
\hline $36-45$ years & 148 & 50.0 & 100 & 33.7 \\
\hline More than 45 years & 26 & 8.8 & 2 & 0.8 \\
\hline \multicolumn{5}{|l|}{ Marital Status } \\
\hline Married & 276 & 93.4 & 249 & 84.5 \\
\hline Single & 19 & 6.6 & 46 & 15.5 \\
\hline
\end{tabular}




\begin{tabular}{|c|c|c|c|c|c|c|c|}
\hline \multicolumn{8}{|c|}{ Qualification } \\
\hline \multicolumn{3}{|c|}{ Graduate } & \multicolumn{2}{|c|}{52} & 17.5 & 43 & 14.5 \\
\hline \multicolumn{3}{|c|}{ Masters } & \multicolumn{2}{|c|}{218} & 74.1 & 204 & 69.2 \\
\hline \multicolumn{3}{|c|}{ M.Phil/ MS } & \multicolumn{2}{|c|}{25} & 8.4 & 48 & 16.3 \\
\hline \multicolumn{8}{|c|}{ Bank Type } \\
\hline \multicolumn{3}{|c|}{ Islamic } & \multicolumn{2}{|c|}{53} & 17.8 & 53 & 17.8 \\
\hline \multicolumn{3}{|c|}{ Conventional } & \multicolumn{2}{|c|}{242} & 82.2 & 242 & 82.2 \\
\hline \multicolumn{8}{|c|}{ Total Experience } \\
\hline \multicolumn{3}{|c|}{ Less than 5 years } & \multicolumn{2}{|c|}{12} & 4.2 & 18 & 6.2 \\
\hline \multicolumn{3}{|c|}{$6-10$ years } & \multicolumn{2}{|c|}{119} & 40.2 & 170 & 57.7 \\
\hline \multicolumn{3}{|c|}{11 - 15 years } & \multicolumn{2}{|c|}{111} & 37.7 & 86 & 29.3 \\
\hline & ore than 1 & ears & & & 17.9 & 21 & 6.8 \\
\hline & Table-3: 1 & an, Star & d Devi & on and Co & rrelation & Analysis & \\
\hline & Mean & S.D. & WPE & PSYCAP & OCBI & ОСВО & OP \\
\hline WPE & 5.78 & .962 & 1 & & & & \\
\hline PSYCAP & 5.25 & .948 & $.131^{*}$ & 1 & & & \\
\hline OCBI & 4.98 & 1.086 & $.388^{* *}$ & $.271^{*}$ & 1 & & \\
\hline OCBO & 3.98 & 1.410 & .027 & .048 & $.168^{*}$ & 1 & \\
\hline OP & 5.22 & .935 & $.363^{* *}$ & $.172^{*}$ & $.482^{* *}$ & $.178^{* *}$ & 1 \\
\hline $\begin{array}{l}\text { ** Correla } \\
\text { WPE }= \\
\text { Citizen }\end{array}$ & $\begin{array}{l}\text { tion is sig } \\
\text { orkplace } \\
\text { hip Behav }\end{array}$ & $\begin{array}{l}\text { cant at } \\
\text { vy; PSY } \\
\text {-Indivi } \\
\text { nizatio }\end{array}$ & $\begin{array}{l}0.01 \mathrm{lev} \\
0.05 \mathrm{lev} \\
\mathrm{P}=\mathrm{Psyc} \\
; \mathrm{OCBC} \\
\mathrm{P}=\text { Orga }\end{array}$ & $\begin{array}{l}\text { (2-tailed). } \\
\text { (2-tailed). } \\
\text { logical Cap } \\
\text { Organizati } \\
\text { zational Pe }\end{array}$ & $\begin{array}{l}\text { * Correlat } \\
\text { ital; OCB } \\
\text { ional Citiz } \\
\text { erformanc }\end{array}$ & $\begin{array}{l}\text { on is signif } \\
=\text { Organiza } \\
\text { enship Beh } \\
\end{array}$ & $\begin{array}{l}\text { icant a } \\
\text { tional } \\
\text { avior- }\end{array}$ \\
\hline
\end{tabular}

\section{Measurement Model}

Confirmatory factor analysis (CFA) is used to predict the measurement model and psychometric properties of variables. Results of GOF came out impressive as CMIN/DF is reported at 4.339 (excellent), RMR at .049 (excellent), values of GFI, AGFI, NFI AND CFI are .990, .928, .956 and .965 and the value of RMSEA is acceptable at .062. Concerning scale level CFA, scales showed good validity and reliability results. Variance extracted at 0.62 , well above the criteria of 0.50 (Anderson \&Gerbing, 1988), reassuring the discriminant validity of the constructs (Table-4).

\begin{tabular}{lrcccc}
\hline Table-4: Scale Level Reliability Analysis & & & & \\
\hline Scales & N & $\begin{array}{l}\text { Cronbach } \\
\text { Alpha } \alpha\end{array}$ & CR & AVE \\
\hline Workplace Envy & 5 & .887 & .887 & .614 \\
\hline & 103 & & &
\end{tabular}




\begin{tabular}{|c|c|c|c|c|c|c|}
\hline \multicolumn{3}{|c|}{ Psychological Capital } & \multirow{2}{*}{$\begin{array}{l}12 \\
7\end{array}$} & \multirow{2}{*}{$\begin{array}{l}.869 \\
.865\end{array}$} & \multirow{2}{*}{$\begin{array}{l}.860 \\
.837\end{array}$} & \multirow{2}{*}{$\begin{array}{l}.507 \\
.510\end{array}$} \\
\hline $\begin{array}{l}\text { Organizational } \\
\text { Individual }\end{array}$ & Citizenship & Behavior- & & & & \\
\hline $\begin{array}{l}\text { Organizational } \\
\text { Organization }\end{array}$ & Citizenship & Behavior- & 6 & .901 & .914 & .682 \\
\hline Organizational & erformance & & 10 & .930 & .930 & .573 \\
\hline
\end{tabular}

Moreover, good factor loadings (above 0.5) are reported on a five-factor model on the criteria of a cut-off value of 0.32 (Velicer \& Fava, 1998; Tabachnick\& Fidell, 2001). Similarly, the reliability of the constructs is assured through the values of Cronbach's alpha which stood well above the criteria of 0.70 for all the constructs (Hair et al., 2006, 2010). Same is the case with CR values (Murphy \& Balzer, 1989) as shown in the table-4.

\section{Hypothesis Testing}

The direct positive association between WPE and OCBI is reported $(\beta=.385$, $p<0.01)$, which supported the hypothesis $\mathrm{H}_{1}($ Table-5). However, hypothesis $\mathrm{H} 2$ is not supported as no association is reported between WPE and OCBO $(\beta=.034, N S)$. The third hypothesis, i.e., H3, is supported as a positive direct association is reported between WPE and OP $((\beta=.358, p<0.01)$. Moving to the next hypothesis, a direct positive association is reported between PsyCap and OCBI, approving the hypothesis H4 $(\beta=.120, p<0.05)$. Similarly, hypotheses H5 and H6 are also supported as direct positive associations are reported between PsyCap \& OCBO $(\beta=.052$, $p<0.01)$ and PsyCap \& OP $(\beta=.125, p<0.05)$. Path diagram is also given in the figure-2 below.

\section{Table-5: Standardized Regression Weights for Structural Model (Hypothesized)}

\begin{tabular}{cccccc}
\hline Hypothesis & & & & Estimates & P-value \\
\hline $\mathrm{H}_{1}$ & Workplace Envy & $------->$ & OCB-Individual & 0.385 & $* * *$ \\
\hline $\mathrm{H}_{2}$ & Workplace Envy & $------>$ & OCB-Organization & 0.034 & 0.055 \\
\hline $\mathrm{H}_{3}$ & Workplace Envy & $------->$ & $\begin{array}{c}\text { Organization } \\
\text { Performance }\end{array}$ & 0.358 & $* * *$ \\
\hline $\mathrm{H}_{4}$ & $\begin{array}{c}\text { Psychological } \\
\text { Capital }\end{array}$ & $------>$ & OCB-Individual & 0.120 & $* *$ \\
\hline $\mathrm{H}_{5}$ & $\begin{array}{c}\text { Psychological } \\
\text { Capital }\end{array}$ & $------>$ & OCB-Organization & 0.052 & $*$ *** \\
\hline $\mathrm{H}_{6}$ & $\begin{array}{c}\text { Psychological } \\
\text { Capital }\end{array}$ & $---->$ & $\begin{array}{c}\text { Organization } \\
\text { Performance }\end{array}$ & 0.125 & $* *$ \\
\hline $\begin{array}{c}* * * \\
P<0.01\end{array}$ & & & & \\
\hline
\end{tabular}


Figure 1: Path Diagram with Regression Weights

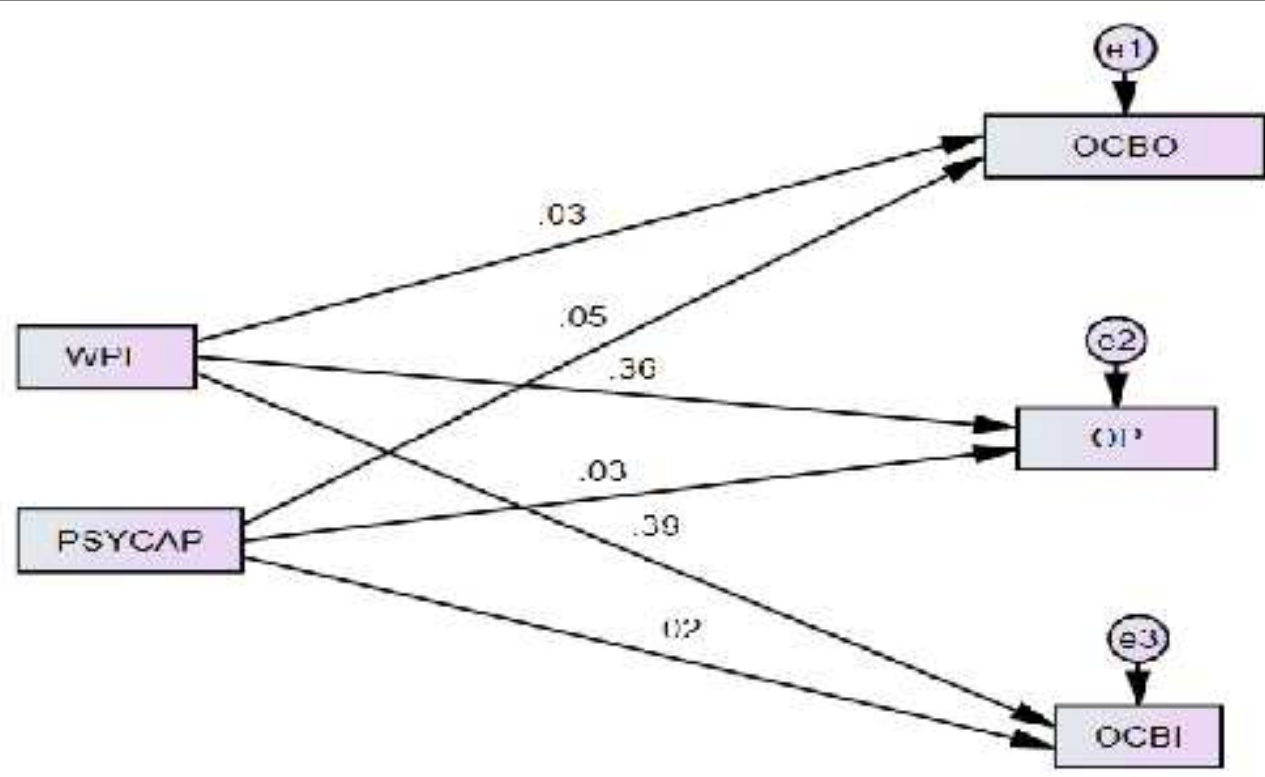

Referring to the table- 6 below, it is evident that the impact of WPE is more substantial on the outcomes in comparison with PsyCap for two out of three outcomes such as OCBI $(\Delta \beta=.238)$ and OP $(\Delta \beta=.233)$. Hence hypothesis H7 and H9 are supported. However, in the case of hypothesis H8, i.e., OCBO, PsyCap generated more positive impact than WPE with a minor difference $(\Delta \beta=-.018)$ which represented no support of this hypothesis.

Table 6: Comparative Presentation of Regression Weights (Hypothesized)

\begin{tabular}{cccccc}
\hline Hypothesis & Outcomes & WPE & PsyCap & Change & Result \\
\hline $\mathrm{H}_{7}$ & OCB-Individual & $.385^{* * *}$ & $.120^{* *}$ & .238 & Supported \\
\hline $\mathrm{H}_{8}$ & $\begin{array}{c}\text { OCB- } \\
\text { Organization }\end{array}$ & .034 & $.052^{* * *}$ & -.018 & Not Supported \\
\hline $\mathrm{H}_{9}$ & $\begin{array}{c}\text { Organizational } \\
\text { Performance }\end{array}$ & $.358^{* * *}$ & $.125^{* *}$ & .233 & Supported \\
\hline $\begin{array}{c}* * * \\
\text { ** } P<0.01\end{array}$ & & & & \\
\hline
\end{tabular}

\section{Discussion}

While envy is an inevitable emotion, an effort is made to understand the implication of positive side of envy that if organizations should promote or curb it. It is discovered that while envy is a complex emotion, organizations should make an effort to instill and elicit the positive side of envy as it works as a stronger 
motivational force for employees and ultimately contribute in better individual as well as organizational outcomes. In order to test this model, we have taken positive outcomes such as OCBI, OCBO and OP. These outcomes were taken for two notable reasons. First, OCB constitutes voluntary work behaviours, and if an employee is committed towards voluntary work behaviours, his commitment towards formal work behaviours will become less questionable. Second, individual performance is useless if not translated in broader organizational performance; hence we have taken organizational performance as an outcome as well in this study. We tested these outcomes against two antecedents, such as WPE and PsyCap, simultaneously. After observing the positive relation between WPE and outcomes, we tested if it works as a stronger force in igniting the positive outcomes in comparison with PsyCap. We came up with rather impressive results, while WPE worked as a stronger motivational force to promote OCBI and OP, it showed no significant association with OCBO. We observed that as envy is related to the individual emotional level and OCBO is related to the broader organizational level, hence association is not found. Moreover, similar findings are reported through correlation analysis provided in the table- 4 above, where no correlation is reported between WPE and OCBO $(r=.027, N S)$.

Concerning the Social Exchange Theory (SET), this study contributes to the literature on the activity dimension, which was introduced by Cropanzano et al. (2017). Activity dimension consists of active as well as inactive exchanges. For instance, praise from the supervisor shall be reciprocated as more loyalty from the subordinate. Literature is of the view that positive initiating action would garner positive responses, and negative responses would be reciprocated as a result of adverse initiating action (Cropanzanoet al., 2017). This is where this study proposes an alternative explanation that positive initiating action can generate adverse outcomes as well (feeling bad on the promotion of best friend). Hence its less important to control the initiating action than to manage the resulting emotion. Hence, suffice to say is that as envy is inevitable, if goes unmanaged can harm the organization. Furthermore, if we can manage this envy, favourable outcomes, as a result, are far more impactful than steering efforts for positive antecedents such as developing PsyCap.

\section{Conclusions}

This study provides a critical decision criterion for the managers and organizations whether they should focus on developing PsyCap in their employees or they should embark upon more unusual way i.e.,enticing envy in employees to achieve favorable outcomes. It is reported that envy works as a stronger motivational force for organizations towards favorable outcomesthan traditional PsyCap itself.

\section{Recommendations}

As envy is such a strong emotion that it has its roots at almost all levels in all the organizations (Menon \& Thompson, 2010), hence it has similar organizational 
wide implications. Hence the implication of this study ranges from employees (for better understanding and implications of envy and hence better self-control), managers (better management with emotional intelligence of subordinates) to organizations (training programs to promote benign envy for better outcomes). Hence organizations should direct more resources in regulating envy than curbing it. This way, additional resources which are exhausted in the development and promotion of PsyCap can be saved. 


\section{References}

ANDERSON, J. Y. G. DW (1988). Structural equation modelling in practice: a review and recommended two-step approach. Psychological Bulletin, 103(3), 411-423.

Bishop, J. W., Scott, K. D., \& Burroughs, S. M. (2000). Support, commitment, and employee outcomes in a team environment. Journal of management, 26(6), 11131132.

Blau, P. M. 1964. Exchange and power in social life. New York: John Wiley.

Bogler, R., \& Somech, A. (2005). Organizational citizenship behavior in school: how does it relate to participation in decision making?. Journal of Educational Administration, 43(5), 420-438.

Chernyak-Hai, L., \&Rabenu, E. (2018). The new era workplace relationships: Is social exchange theory still relevant?. Industrial and Organizational Psychology, 11(3), 456481.

Cho, J., \& Dansereau, F. (2010). Are transformational leaders fair? A multi-level study of transformational leadership, justice perceptions, and organizational citizenship behaviors. The Leadership Quarterly, 21(3), 409-421.

Cooper-Thomas, H. D., \& Morrison, R. L. (2019). Give and Take: Needed Updates to Social Exchange Theory. Industrial and Organizational Psychology, 11(3), 493-498.

Cropanzano, R., \& Mitchell, M. S. (2005). Social exchange theory: An interdisciplinary review. Journal of management, 31(6), 874-900.

Cropanzano, R., Anthony, E. L., Daniels, S. R., \& Hall, A. V. (2017). Social exchange theory: A critical review with theoretical remedies. Academy of Management Annals, 11(1), 479-516.

Cropanzano, R., Anthony, E. L., Daniels, S. R., \& Hall, A. V. (2015). Social exchange theory: A critical review with theoretical remedies. Academy of Management Annals, 11, 1-38.

Dineen, B. R., Duffy, M. K., Henle, C. A., \& Lee, K. (2017). Green by comparison: Deviant and normative transmutations of job search envy in a temporal context. Academy of Management Journal, 60(1), 295-320.

DiPaola, M. F., \& Hoy, W. K. (2005). Organizational citizenship of faculty and achievement of high school students. The High School Journal, 88(3), 35-44.

Duffy, M. K., Ganster, D. C., \& Pagon, M. (2002). Social undermining in the workplace. Academy of management Journal, 45(2), 331-351. 
Eissa, G., \& Wyland, R. (2016). Keeping up with the Joneses: The role of envy, relationship conflict, and job performance in social undermining. Journal of Leadership \& Organizational Studies, 23(1), 55-65.

Erdil, O., \&Müceldili, B. (2014). The effects of envy on job engagement and turnover intention. Procedia-Social and Behavioral Sciences, 150, 447-454.

Fischer, A. H., \& Van Kleef, G. A. (2010). Where have all the people gone? A plea for including social interaction in emotion research. Emotion Review, 2(3), 208-211.

Ghadi, M. Y. (2018). Empirical examination of theoretical model of workplace envy: evidences from Jordan. Management Research Review, 41(12), 1438-1459.

Gouldner, A.W. 1960. The norm of reciprocity: A preliminary statement. American Sociological Review, 25: 161-178.

Hair, J. F., Black, W. C., Babin, B. J., \& Anderson, R. E. (2010). Multivariate data analysis: A global perspective 7 edn.

Hair, J. F., Black, W. C., Babin, B. J., Anderson, R. E., \& Tatham, R. L. (2006). Multivariate data analysis 6th Edition. Pearson Prentice Hall. New Jersey. humans: Critique and reformulation. Journal of Abnormal Psychology, 87, 49-74.

Hobfoll, S. E. (1989). Conservation of resources: A new attempt at conceptualizing stress. American psychologist, 44(3), 513.

Hobfoll, S. E. (2002). Social and psychological resources and adaptation. Review of general psychology, 6(4), 307-324.

Hodges, Timothy Daniel, "An Experimental Study of the Impact of Psychological Capital on Performance, Engagement, and the Contagion Effect" (2010). Dissertations, Theses, and Student Research from the College of Business. 7.

Kang, X., Zhang, B., Bi, Y., \& Huang, X. (2019). The effect of malicious envy on the framing effect: The mediating role of fear of failure. Motivation and Emotion, 1-14.

Karatepe, O. M., Ozturk, A., \& Kim, T. T. (2019). The effects of nonwork and personal resources on frontline bank employees' work engagement and critical job outcomes. International Journal of Bank Marketing, 37(3), 858-879.

Kasa, M., \& Hassan, Z. (2015). The role of flow between burnout and organizational citizenship behavior (OCB) among hotel employees in Malaysia. Procedia-Social and Behavioral Sciences, 211, 199-206.

Kataria, A., Garg, P., \& Rastogi, R. (2012). Employee Engagement and Organizational Effectiveness: The Role of Organizational Citizenship Behavior. International Journal of Business Insights \& Transformation, 6(1). 
Keltner, D., \& Haidt, J. (1999). Social functions of emotions at four levels of analysis. Cognition \& Emotion, 13(5), 505-521.

Kim, E., \& Glomb, T. M. (2014). Victimization of high performers: The roles of envy and work group identification. Journal of applied psychology, 99(4), 619.

Lange, J., \& Crusius, J. (2015). Dispositional envy revisited: Unraveling the motivational dynamics of benign and malicious envy. Personality and social psychology bulletin, 41(2), 284-294.

Lange, J., Weidman, A. C., \& Crusius, J. (2018). The painful duality of envy: Evidence for an integrative theory and a meta-analysis on the relation of envy and schadenfreude. Journal of Personality and Social Psychology, 114(4), 572.

Lee, K., \& Allen, N. J. (2002). Organizational citizenship behavior and workplace deviance: The role of affect and cognitions. Journal of applied psychology, 87(1), 131.

Lee, K., \& Duffy, M. K. (2019). A functional model of workplace envy and job performance: When do employees capitalize on envy by learning from envied targets?. Academy of Management Journal, 62(4), 1085-1110.

Luthans, F., Avolio, B. J., Avey, J. B., \& Norman, S. M. (2007). Positive psychological capital: Measurement and relationship with performance and satisfaction. Personnel Psychology, 60(3), 541-572.

Luthans, F., Norman, S. M., Avolio, B. J., \& Avey, J. B. (2008). The mediating role of psychological capital in the supportive organizational climate-employee performance relationship. Journal of Organizational Behavior: The International Journal of Industrial, Occupational and Organizational Psychology and Behavior, 29(2), 219-238.

Luthans, F., Youssef, C. M., \& Avolio, B. J. (2007). Psychological capital: Developing the human competitive edge. Oxford University Press.

Malinowski, B. 1922. Argonauts of the western Pacific: An account of native enterprise and adventure in the archipelagoes of Melansian New Guinea. London: Routledge

Menon, T., \& Thompson, L. (2010). Envy at work. Harvard Business Review, 88(4), 7479.

Murphy, K. R., \& Balzer, W. K. (1989). Rater errors and rating accuracy. Journal of applied psychology, 74(4), 619.

Organ, D. W. (1988). Organizational citizenship behavior: The good soldier syndrome. Lexington Books/DC Heath and Com.

Organ, D. W. (1990). The motivational basis of organizational citizenship behavior. Research in Organizational Behavior, 12(1), 43-72. 
Parker, S. K. (1998). Enhancing role breadth self-efficacy: the roles of job enrichment and other organizational interventions. Journal of Applied Psychology, 83(6), 835.

Peng, T., Pike, S., \& Roos, G. (2007). Intellectual capital and performance indicators: Taiwanese healthcare sector. Journal of Intellectual Capital, 8, 538-556.

Saunders, M., Lewis, P., \& Thornhill, A. (2016). Research methods for business studentsSeventh Edition.Pearsons.

Scheier, M. F., \& Carver, C. S. (1985). Optimism, coping, and health: assessment and implications of generalized outcome expectancies. Health Psychology, 4(3), 219.

Shu, C. Y., \& Lazatkhan, J. (2017). Effect of leader-member exchange on employee envy and work behavior moderated by self-esteem and neuroticism. Revista de Psicología del Trabajo y de las Organizaciones, 33(1), 69-81.

Snyder, C. R., Sympson, S. C., Ybasco, F. C., Borders, T. F., Babyak, M. A., \& Higgins, R. L. (1996). Development and validation of the State Hope Scale. Journal of Personality and Social Psychology, 70(2), 321.

State Bank of Pakistan. (2018, December 30). Financial Inclustion: State Bank of Pakistan. Retrieved from State Bank of Pakistan: http://www.sbp.org.pk/Finc/finc.asp

State Bank of Pakistan. (2019, December 7). Members Financial Institutions: State Bank of Pakistan. Retrieved from State Bank of Pakistan: http://www.sbp.org.pk/ecib/members.htm

State Bank of Pakistan. (2019, March). Islamic Banking Bulletin: State Bank of Pakistan. Retrieved from State Bank of Pakistan: http://www.sbp.org.pk/ibd/bulletin/2019/Mar.pdf

Statista. (2017, December). Statista: Business Services. From Statista:https://www.statista.com/statistics/802832/average-training-budgetworldwide-by-company-size/

Tabachnick, B. G., \& Fidell, L. S. (2001). Principal components and factor analysis. Using multivariate statistics, 4(1), 582-633.

Tai, K., Narayanan, J., \& McAllister, D. J. (2012). Envy as pain: Rethinking the nature of envy and its implications for employees and organizations. Academy of Management Review, 37(1), 107-129.

Tepper, B. J., \& Taylor, E. C. (2003). Relationships among supervisors' and subordinates' procedural justice perceptions and organizational citizenship behaviors. Academy of Management Journal, 46(1), 97-105. 
Thompson, G., Glasø, L., \& Martinsen, Ø. (2015). The relationships between envy and attitudinal and behavioral outcomes at work. Scandinavian Journal of Organizational Psychology, 7(1), 5-18.

Tomal, D. R., \& Jones, K. J. (2015). A comparison of core competencies of women and men leaders in the manufacturing industry. The Coastal Business Journal, 14(1), 13.

Van de Ven, N. (2016). Envy and its consequences: Why it is useful to distinguish between benign and malicious envy. Social and Personality Psychology Compass, 10(6), 337-349.

Van de Ven, N., Zeelenberg, M., \& Pieters, R. (2012). Appraisal patterns of envy and related emotions. Motivation and emotion, 36(2), 195-204.

Vecchio, R. (2005). Explorations in employee envy: Feeling envious and feeling envied. Cognition \& Emotion, 19(1), 69-81.

Velicer, W. F., \& Fava, J. L. (1998). Affects of variable and subject sampling on factor pattern recovery. Psychological methods, 3(2), 231.

Vince, R. (2001). Power and emotion in organizational learning. Human Relations, 54(10), 1325-1351.

Wagnild, G. (2009). A review of the Resilience Scale. Journal of Nursing Measurement, 17(2), 105-113.

Williams, L. J., \& Anderson, S. E. (1991). Job satisfaction and organizational commitment as predictors of organizational citizenship and in-role behaviors. Journal of management, 17(3), 601-617.

Zeinabadi, H., \& Salehi, K. (2011). Role of procedural justice, trust, job satisfaction, and organizational commitment in Organizational Citizenship Behavior (OCB) of teachers: Proposing a modified social exchange model. Procedia-Social and Behavioral Sciences, 29, 1472-1481.

Zeinabadi, H., \& Salehi, K. (2011). Role of procedural justice, trust, job satisfaction, and organizational commitment in Organizational Citizenship Behavior (OCB) of teachers: Proposing a modified social exchange model. Procedia-Social and Behavioral Sciences, 29, 1472-1481. 